\title{
What the radiologist needs to know about restaging of rectal carcinoma after chemoradiation therapy
}

\author{
ME Nazar", F Grana, L Alarcon, G Caimi Romero, N Rotholtz, EP Eyheremendy \\ From International Cancer Imaging Society (ICIS) 14th Annual Teaching Course \\ Heidelberg, Germany. 9-11 October 2014
}

\begin{abstract}
Aim
The purpose of this exhibit is to describe and compare the high-resolution MRI features of rectal carcinoma after chemoradiation treatment (CRT) and to correlate with the histologic findings after total mesorectal excision (TME).
\end{abstract}

\section{Method}

High resolution T2-W MR imaging (HRMRI) was performed in a $1.5 \mathrm{~T}$ unit between January 2013 and February 2014 before and immediately after CRT in the care of 25 patients with locally advanced adenocarcinoma of the rectum. After total mesorectal excision (TME) the piece was cut by the pathologist under the supervision of the radiologist, who indicated areas of residual tumour after neoadjuvant therapy or changes such as fibrosis, oedema, cellular and acellular mucin, desmoplastic reaction and pseudotumour appearance. Thus, initially we did a correlation between the macroscopic and MR imaging. Subsequently, we performed the same correlation but in this case between microscopy and MR imaging. Changes in morphologic and signal intensity features were evaluated with respect to primary tumour and nodal downstaging.

\section{Summary}

Emerging evidence has shown the prognostic importance of reassessing rectal cancer using HRMRI after completion of CRT. A systematic cooperation between radiologist and pathologist is essential for optimal treatment planning and patient care.
Published: 9 October 2014

doi:10.1186/1470-7330-14-S1-P16

Cite this article as: Nazar et al:: What the radiologist needs to know about restaging of rectal carcinoma after chemoradiation therapy. Cancer Imaging 2014 14(Suppl 1):P16.

\footnotetext{
* Correspondence: m69nazar@gmail.com German Hospital, Buenos Aires, Argentina
}

Submit your next manuscript to BioMed Central and take full advantage of:

- Convenient online submission

- Thorough peer review

- No space constraints or color figure charges

- Immediate publication on acceptance

- Inclusion in PubMed, CAS, Scopus and Google Scholar

- Research which is freely available for redistribution

Submit your manuscript at www.biomedcentral.com/submit
( Biomed Central

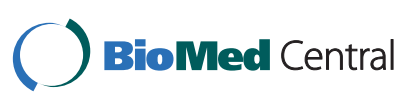

